\title{
Cytological Characteristics of Mucose Cell and Vaginal Temperature and pH During Estrous Cycle in Local Sheep
}

\author{
Siti Darodjah Rasad*and Rangga Setiawan \\ Animal Reproduction \& Al Laboratory, Animal Husbandry Faculty, Universitas Padjadjaran \\ Jl. Raya Bandung-Sumedang KM 21, Campus Jatinangor, Sumedang-Indonesia \\ *Corresponding author email: s.d.rasad@unpad.ac.id
}

\begin{abstract}
The aim of this study was to examine the cytological characteristics of mucous cell and vaginal temperature and $\mathrm{pH}$ during estrous cycle in 30 local sheep. Synchronization of estrous was using vaginal sponge impregnated with $20 \mathrm{mg}$ progesterone prior to observations of cytology of cells from vaginal mucose through vaginal swabs to measure vaginal temperature and $\mathrm{pH}$. Vaginal swabs were collected daily at 07.00 am for a week. Vaginal temperature and pH were measured twice a day at 07.00 am and $15.00 \mathrm{pm}$ for a week after vaginal swabs. The smears of the swab were prepared on glass slide and stained with Giemsa. The study used descriptive statistical method and the parameters were cytology of vaginal cells and vaginal temperature and $\mathrm{pH}$ during estrous cycle. Vaginal epithelial cells classfied into parabasal, intermediate and superficial cells were counted and determined the percentage during proestrous, estrous and diestrous. Observation on vaginal temperature showed that the highest temperature $\left(39.08 \pm 0.28^{\circ} \mathrm{C}\right)$ was obtained on the third day. It can be concluded that during estrous phase, cytology of vaginal mucose cell was dominated by superficial cell and both vaginal temperature and $\mathrm{pH}$ increased.
\end{abstract}

Key words : cytology, vaginal temperature, vaginal $\mathrm{pH}$, estrous cycle, sheep

Abstrak. Tujuan dari penelitian ini adalah untuk menguji karakteristik sitologi dari sel-lendir, suhu dan vaginanya $\mathrm{pH}$ selama siklus estrus pada domba lokal. Sebanyak 30 ekor domba lokal yang disinkronisasi dengan spons vagina yang mengandung $20 \mathrm{mg}$ hormon progesteron. Sebelum dilakukan pengamatan sitologi sel dari mucose vagina melalui apusan vagina, dilakukan pengukuran suhu dan $\mathrm{pH}$ vagina. Apusan vagina dilakukann setiap hari pada pukul 07.00 pagiselama seminggu. Pengukuran Suhu vagina dan pH dilakukan dua kali sehari, pada pukul 07.00 WIB dan 15.00 WIB selama satu minggu setelah apusan vagina. Metode statistik yang digunakan adalah deskriptif dengan parameter yang diteliti adalah sitologi sel vagina, temperatur dan $\mathrm{pH}$ vagina selama siklus estrus. Pengamatan sel epitel vagina; Parabasal, sel intermediate dan keratin diamati dan dilakukan penghitungan persentase sel yang muncul selama pro-estrus, estrus dan di-estrus. Pengamatan suhu vagina tertinggi diperoleh pada hari ketiga yaitu $39,08 \pm 0,28^{\circ} \mathrm{C}$. Dari hasil penelitian dapat disimpulkan bahwa selama fase estrus, sitologi sel mucose vagina didominasi oleh sel superfisial dan suhu vagina serta $\mathrm{pH}$ vagina meningkat.

Kata Kunci : sitologi, temperatur, pH vagina, siklus estrus, domba

\section{Introduction}

Behavioral estrous in livestock animal like sheep or cattle can be detected from the exterior behavior or changes in vaginal cytology during estrous cycle. During ovulation, there are changes in ratio of cornification of the epithelial cells and basal cell (Zaid, 2011), and change in behaviour, body temperature and physical properties of genitals fluids of female cattle due to reproductive hormone status during estrous cycle (Redden et al., 1993). Evaluation of estradiol levels, vaginal cytology, and the appearance of the vulva can be used as a predictor of the estrous cycle in female (Mayor et al., 2006). During estrous, sheep will be affected by estrogen and the symptom of estrous will appear visually from the behavior or changes in the vulva of the sheep. However, sheep often experience reproductive disorder like silent estrous which is a phenomenon of ovulation without signs of estrous, especially common in young sheep. Silent estrus often occurs during the first estrus cycle, which may also be due to estrogen deficiency. In these conditions, the female sheep will not show the symptoms of estrus so it cannot be detected visually. Determination of this estrus cycle in 
addition to visual observations can be done by the vaginal smear method. Through this method the changes of cytology of epithelial cell and polyneclear leucocyte cells in the vaginal mucus can be seen (Vidal et al., 2013).

To date, research on the characteristics of vaginal cytology during estrous cycle in local sheep is still limited. Therefore, the objective of this research is to examine the characteristics cytology of vaginal mucous cell, temperature and $\mathrm{pH}$ during estrous cycle in local sheep.

\section{Materials and Methods}

The descriptive research used 31 local sheep for synchronization using vaginal sponge impregnated with $20 \mathrm{mg}$ progesterone hormone before vagina swab as the sample. Upon sponge removal, vaginal swab was conducted every day at 7 am for a week. Estrous phase was justified through estrous symptom and cervix dilatation using speculum and then evaluated the condition of the cervix. Vaginal temperature and $\mathrm{pH}$ was measured twice a day (at 7 am and $3 \mathrm{pm}$ ) for a week using thermometer and $\mathrm{pH}$ meter. Smears of the vaginal swab were then prepared on glass slide and stained with Giemsa.

Parameters of the research were (1) cytology cell of mucous vagina. Vaginal epithelial cells classified into parabasal, intermediate and superficial cells were counted and the percentage during proestrous, estrous and diestrous was determined. Diestrous was characterized by the absence of superficial cells in the epithelial vaginal, while progressive increase in percentage of intermediate/ superficial cells in epithelial vagina characterized proestrous and superficial/ cornification cells in most vaginal epithelial vagina indicates diestrus; (2) temperature vagina, and (3) $\mathrm{pH}$ vagina.

Statistical analysis was conducted by data tabulation which consisted of day of observation, mean of epithelial cell of mucose vagina (\%), percentage of estrous identified of sheep through dominancy of cell (\%), mean of temperature vagina $\left({ }^{\circ} \mathrm{C}\right)$ and mean of $\mathrm{pH}$ vagina. Epithelial cell was counted from the percentage of parabasal cell, intermediate, superficial cell and ceratine cell with the formula:

\section{Number of cell counted}

$\%$ cell counted = ------------------------- x100\%

Total number of cell

Description of the data, was analyzed through mean of sample and standard deviation.

\section{Results and Discussion}

\section{Estrous detection through cytology of mucose cell of vagina}

The observation of epithelial cells percentage of vaginal mucosa in local sheep consisted of parabasal cell, intermediate cells, superficial cells and ceratine cells is presented in Table 1.

Table 1 explains that vaginal swab on day 1 is dominated by intermediate cell, indicated higher percentage than the other cells. Day 2 shows declining percentage of intermediate, parabasal and ceratine cells, but increasing superficial cell percentage. On day 3 , superficial cell percentage was still higher $(41.03 \%)$ than the other cells, therefore increasing for 2 days straight. According to Widiyono et al. (2011) superficial cell percentage of goat could increase from proestrous to estrous phase and tend to decline after estrous phase because of estradiol change in blood. Day 4 indicates a decline in superficial cell percentage, an increase in while ceratine cell and a stable intermediate cell percentage. On day 5, ceratine cell was high, in contrast with the declining superficial cells, and it prolonged to day 6 and 7. Parabasal cell and intermediate cell began to increase, conversely with superficial 
and ceratine cell. Changes of cytology cells in vaginal mucosa of local sheep are presented in Figure 1.

Cytology changes of vaginal mucosa cell occurred because of changes of hormonal level during estrous activities in ovary. In estrous phase, level estrogen in blood was high, this could be impact to increasing of uterus activities and make hyper secretion, ceratination of epithelial vagina cell and then increased of mitotic cell and proliferation of epithel cell (Popalayah et al., 2013). Ceratination process was important to protect epithelium of vagina from pathogenic invasion between cell or tissues (Hussin et al., 2014). Endogenous bacteria could be metabolized glycogen in cell to lactic acid and could be decline of $\mathrm{pH}$ vagina for the protecting of the pathogenic bacteria.

This observation about cytologies cell of mucose vagina was supported through observation of dilatation of cervix. This justification of cervix dilatation was done to observed peak of estrous and the dominance of cell could be detected. Observation of cervix dilatation is shown in Figure 2.

Table 1. Average Percentage of Epithelial Cells of Mucose Vaginal Identified as a Sheep Estrous

\begin{tabular}{|c|c|c|c|c|c|}
\hline \multirow{3}{*}{ Day } & \multicolumn{4}{|c|}{ Epithelial Cell of mucose vagina } & \multirow{3}{*}{ Number of Sheep estrous } \\
\hline & Parabasal & Intermediate & Superficial & Ceratine & \\
\hline & \multicolumn{4}{|c|}{ 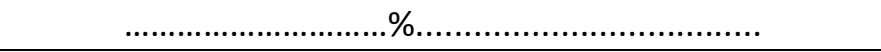 } & \\
\hline 1 & 26.61 & 34.71 & 22.58 & 16.10 & 13 \\
\hline 2 & 20.83 & 31.36 & 32.48 & 15.33 & 26 \\
\hline 3 & 22.14 & 23.46 & 41.03 & 13.37 & 52 \\
\hline 4 & 22.59 & 23.34 & 31.62 & 22.46 & 19 \\
\hline 5 & 23.27 & 21.58 & 17.95 & 37.21 & 16 \\
\hline 6 & 21.16 & 22.19 & 26.81 & 29.84 & 13 \\
\hline 7 & 25.87 & 30.51 & 22.86 & 20.77 & 13 \\
\hline
\end{tabular}

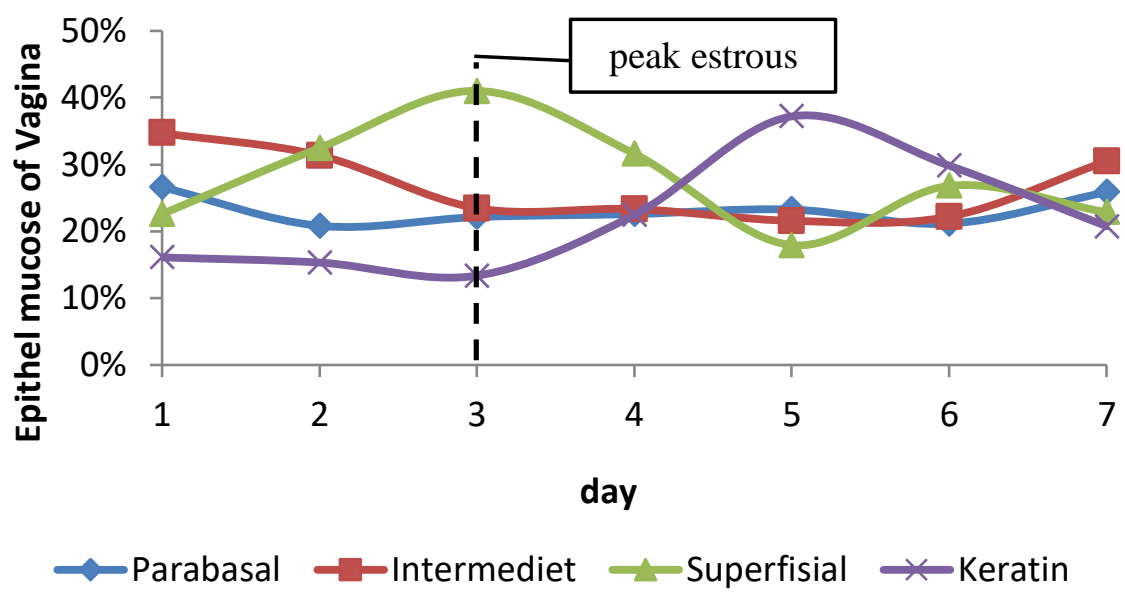

Figure 1. Cytology cells of vaginal mucose of sheep Local 


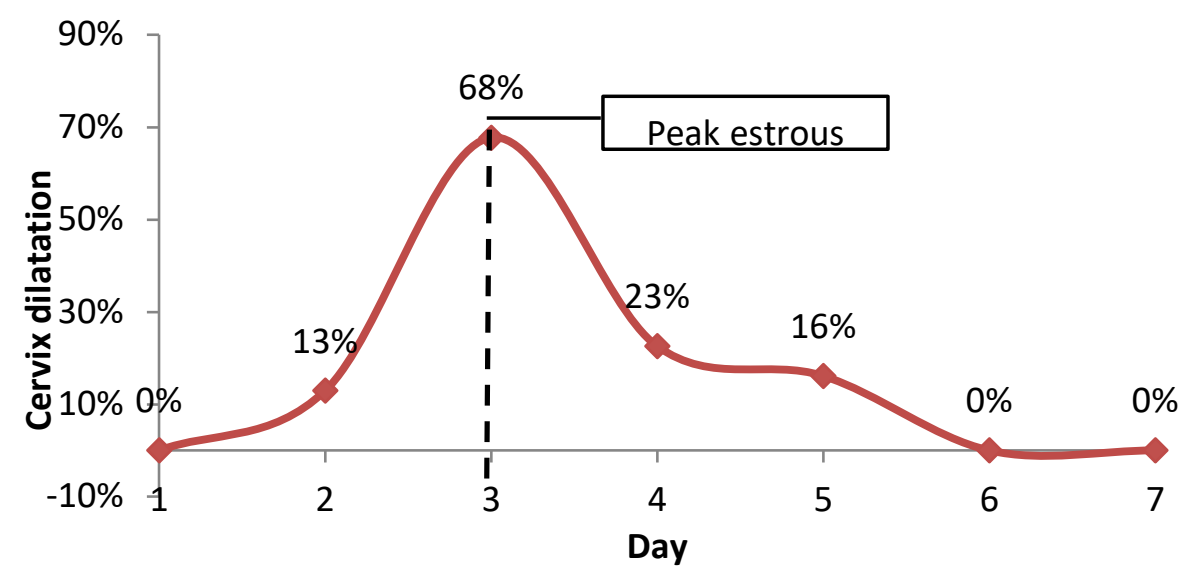

Figure 2. Percentage of Cervix Dilatation

Cervix dilatation is a character of sheep estrous. Based on cervix dilatation observation, the number of female sheep with open cervix or dilated the cervix tend to increase from Day 1 after removal of sponge vaginal to Day 3 , then tend to decline until day 7. Cervix dilatation occurred because of relaxation of cervix and normally done when estrous as a effect of increasing of estradiol level in blood, oxytocin receptor (OxR), cyclooxygenase-2 (COX-2), prostaglandin- $\mathrm{F}_{2 \alpha}\left(\mathrm{PGF}_{2 \alpha}\right)$ (Kershaw et al., 2005). Rodriguez-Pinon et al. (2014) mentioned that estradiol and $\mathrm{LH}$ will be increased during estrous. In pre ovulation, estrogen could be increased sensitivity of cervix as an effect of oxytocin activities and OxR. Oxytocin could be initiate cervix to produce in vitro $\mathrm{PGF}_{2 \alpha}$ and could be affected to mediate COX-2 to catalyzed arachidonic acid to the prostaglandin. Prostaglandin activity then could be effect of cervix dilatation.

In Figure 2 showed, that increasing number of sheep (31 sheep) at day 3 (68\%) was cervix dilated condition. According to Vivanco (1986), sheep will be estrous 2 days after vaginal sponge removed, and began at day 3 estrous was done. Feradis (2010) mentioned that estrous phase could be done $24-36 \mathrm{~h}$ after metestrous phase.

Table 1 showed that day 3 almost sheep were in estrous phase based on superficial cell in vaginal mucose cell and began day 4 until day 7 , the percentage of lamb in estrous phase tend to decline to anestrous phase (Figure 3 ).

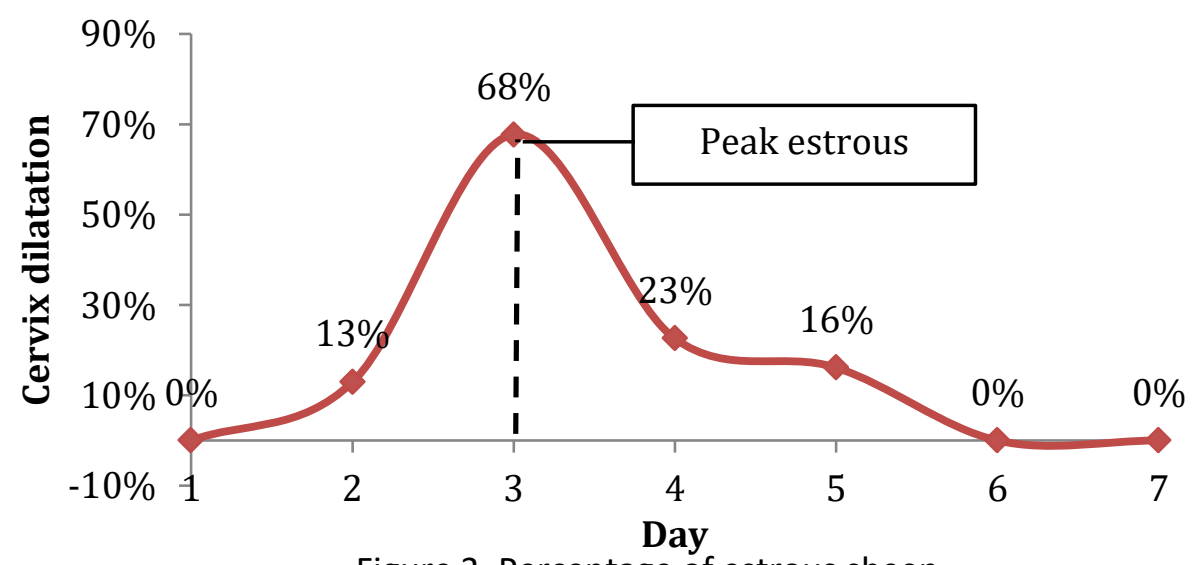

Figure 3. Percentage of estrous sheep 
Temperature was measured twice a day (in the morning and evening) for a week after removing vaginal sponges, as presented in Table 2.

Based on Table 2, the average temperature of the vagina sheep on the first day was $38.96 \pm 0.32^{\circ} \mathrm{C}$, but on the second day the temperature was decline. Otherwise, on the third day when the peak of estrous predetermined through cervical dilatation (Figure 3) was high, and the next day the temperature declined. Vaginal temperature on the third day also showed as a higher temperature than the other days.

On day 5 , the temperature was high after declined on day 4, increased on day 6 and continued to decrease on day 7. The temperatures would increase at the estrous phase, and decreased again at the time of ovulation, the rebound during the luteal phase (Khalifa et al., 2010).

Observation indicated that vaginal temperature during estrous increased on Day 2 from $38.85 \pm 0.29^{\circ} \mathrm{C}$ to $39.08 \pm 0.28^{\circ} \mathrm{C}$ on day 3 , about $48 \mathrm{~h}$ after vaginal sponge removal that was defined as estrous occurence time. The average change of vaginal temperature of local sheep is described in Figure 4.

Vaginal temperature up to $24 \mathrm{~h}$ before estrous increased by $0.23^{\circ} \mathrm{C}$. Previous study on goats by Popalayah et al. (2013) showed that vaginal temperature during estrous increased by $0.4^{\circ} \mathrm{C}$ for $6 \mathrm{~h}$ to $18 \mathrm{~h}$ and decreased gradually from $24 \mathrm{~h}$ to $36 \mathrm{~h}$ before the end of estrous.

Table 2. Temperature Vagina of Local Sheep

\begin{tabular}{|c|c|c|c|}
\hline \multirow{2}{*}{ Day } & Morning Temperature & Evening Temperature & Average \\
\hline & \multicolumn{3}{|c|}{ 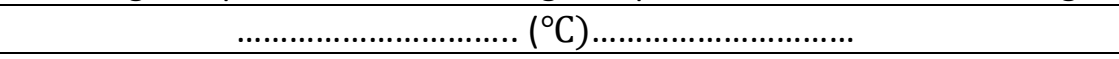 } \\
\hline 1 & $38.75 \pm 0.32$ & $39.17 \pm 0.43$ & $38.96 \pm 0.32$ \\
\hline 2 & $38.78 \pm 0.40$ & $38.92 \pm 0.25$ & $38.85 \pm 0.29$ \\
\hline 3 & $39.06 \pm 0.32$ & $39.09 \pm 0.30$ & $39.08 \pm 0.26$ \\
\hline 4 & $38.97 \pm 0.24$ & $39.00 \pm 0.24$ & $38.98 \pm 0.22$ \\
\hline 5 & $39.05 \pm 0.33$ & $39.05 \pm 0.32$ & $39.05 \pm 0.30$ \\
\hline 6 & $39.09 \pm 0.25$ & $38.94 \pm 0.28$ & $39.01 \pm 0.23$ \\
\hline 7 & $39.01 \pm 0.33$ & $38.95 \pm 0.31$ & $38.98 \pm 0.28$ \\
\hline
\end{tabular}

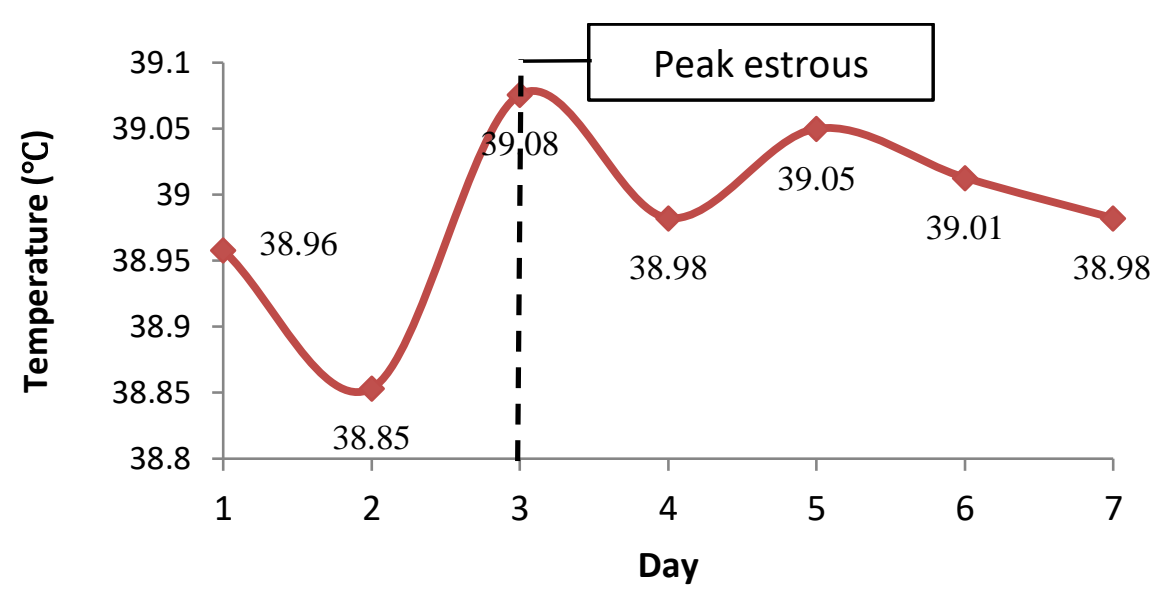

Figure 4. Average of temperature vagina changes of sheep 
Vaginal temperature of sheep increased during estrous phase is the influence of hormonal factors. In the connective tissue of vagina, there are many blood vessels that could form extensive plexus (Hardjopranjoto, 1995). High estrogen at the time of estrous due to increasing blood circulation in the vaginal area and increased fluids in cells resulted in swelling vulva and vagina. Swelling in the vulva and vagina is due to the increased blood flow by estrogen activities and its receptor were found in blood vessels and clinically lowering vascular resistance (Heffner and Danny, 2005).

\section{Estrous detection based on $\mathrm{pH}$ Vagina}

Vaginal $\mathrm{pH}$ conditions during observations could be seen in Figures 5. In that graphic could be seen $\mathrm{pH}$ changes for a week. Based on Figure 5 , the higher $\mathrm{pH}$ of vagina was in day 3 , and this according to the estrous cycle that occurs where the peak estrous was on day 3 after removed of vaginal sponge. At day $2, \mathrm{pH}$ vaginal tend to increase until day 3 , and then continuously decline until day 5 . It was happened that at day 6 and day 7 the $\mathrm{pH}$ vaginal increased back again until maximum 7 and last day of observation was 6.9, because normally $\mathrm{pH}$ vaginal is acidic.

According to animal behavior since estrous phase, normally at that time the female in estrous phase, it was happened increasingly the body temperature as well $\mathrm{pH}$ vaginal. That condition closed related with hormonal activities during estrous period.

Based on data during observation, it could be cleared that $\mathrm{pH}$ vaginal was influenced of reproduction behavior and physiological changes in the reproductive organs can be seen during estrous cycle which is a manifestation of the increased estrogen in the blood. Toelihere (1993) suggest that elevated levels of estrogen lead into estrous female animals that marked the emergence of symptoms of lust like vulva swollen, red, warm, slimy, and silent when ridden by a male. Effect of estrogen results in changes in the physicochemical properties of the mucus of the cervix so that a change in viscosity (Darodjah, 2002). Decrease in vaginal $\mathrm{pH}$ will return coincided with the process of ovulation (Khalifa et al., 2010). Rezac et al. (2001) also reported that at the end of estrous, vaginal mucus is alblaskaline $\mathrm{pH}$. A decrease in vaginal $\mathrm{pH}$ depends on the addition of ions in the vagina, such as hydrogen, sodium and chloride, as well as a decrease in $\mathrm{pH}$ is also caused by the accumulation of glycogen and protein (Khadiga et al., 2005). Blaszczyk et al. (2004) mentioned that the decrease in $\mathrm{pH}$ coincides with the release of $\mathrm{LH}$ in ovulation process.

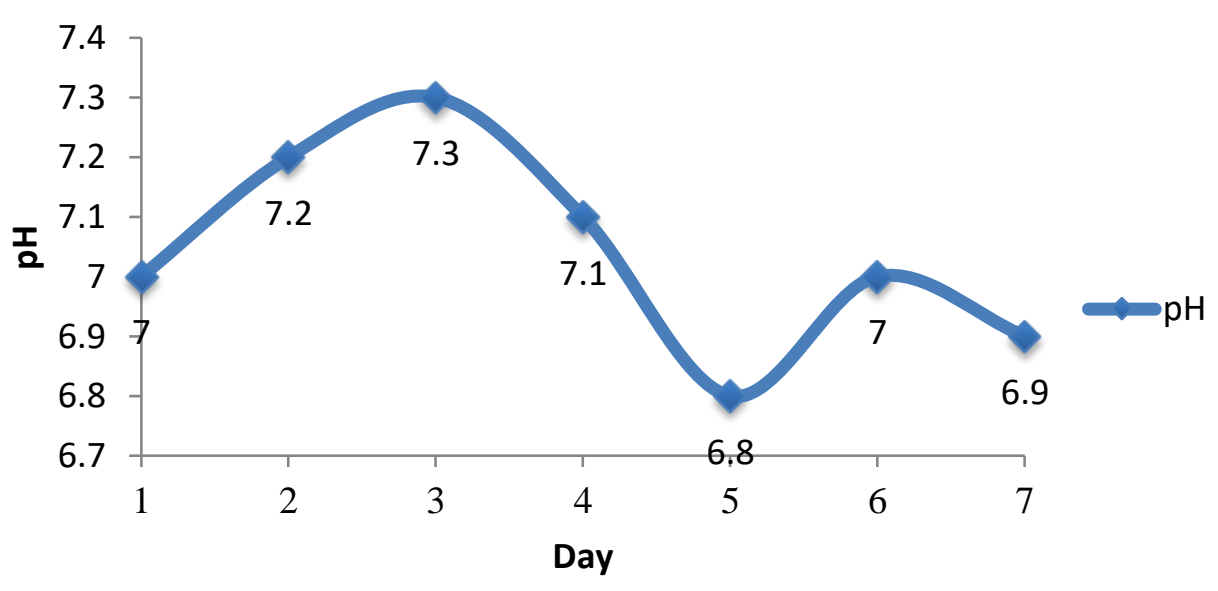

Figure 5. Average data of vaginal-pH changes during observation 


\section{Conclusions}

The study conclude that cytology cells from the vaginal mucus of local sheep during the estrous phase were dominated by superficial cells. During estrous period, vaginal temperature and $\mathrm{pH}$ of local sheep increased.

\section{References}

Blaszczyk B, J Udala, and D Gaczarzewicz. 2004. Changes in estradiol, progesterone, melatonin, prolactin and thyroxin concentrations in blood plasma of goats following induced estrous in and outside the natural breeding season. Small Ruminant Research. 51: 209-219.

Darodjah S. 2002. Animal Reproduction Science. Animal Husbandry Faculty, Padjadjaran University. Bandung.

Feradis MP. 2010. Animal Reproduction. Alfabeta. Bandung. 113-133.

Hardjopranjoto HS. 1995. Animal reproduction disorders. Airlangga University Press. Surabaya. 28.

Heffner $L$ and Danny JS. 2005. At a Glance of Reproductive System. Second Edition. Erlangga. Jakarta. 57.

Hussin AM, NW Zaid, and SO Hussain. 2014. Compensatory Structural Adaptive Modifications of Vagina in Response to Functional Demand in Goat. Veterinary Medicine International Volume 2014. Hindawi Publishing Corporation. Article ID 789816.

Kershaw CM, M Khalid, MR McGowan, K Ingram, S Leethongdee, G Wax and RJ Scaramuzzi. 2005. The Anatomy of the Sheep Cervix and Its Influence on The Transcervical Passage of an Inseminating Pipette into The Uterine Lumen. Theriogenology. 64. Issue 5: 1225-1235.

Khadiga MG, KG Mohamed and FT Doaa. 2005. The hormonal profile during the estrous cycle and gestation in damascus goats. Small Ruminant Research. 57: 85-93.

Khalifa El, Ahmed ME, Abdel-Gaward AM and ElZelaky OA. 2010. The Effect of Insemination Timing on Fertilization and Embryo Gender in Zaraibi Goats. Egyptian Journal of Sheep and Goat Sciences 5(1):274-275.
Mayor P, DA Guimaraes, FL Gatius and ML Bej. 2006. First postpartum estrous and pregnancy in the female collared peccary (Tayassu tajacu) from the amazon. Theriogenology. 66, Issue 8: 2001-2007

Popalayah, Ismaya, and N Ngadiyono. 2013. Effectivity of Controlled Internal Drug Release Usedon Estrous Response and Concentration of Estrogen Hormones in Kacang and Bligon Goats. Animal Husbandry Bulletin 37(3):151-152.

Redden KD, Kennedy AD, Ingalls, JR and Gilson TL. 1993. Detection of estrous by radiotelemetnc monitoring of vaginaland ear skin temperature and pedometer measurements of activity. Journal of Dairy Science. 76: 713-721.

Rezac P, I Krivánek, and M Pöschl. 2001. Changes of vaginal and vestibular impedance in dairy goats during the estrous cycle. Small Ruminant Research 42(3):183-188.

Rodriguez-Pinon M, Gonzalez R, Tasende C, Bielli A, Genovese P and GarofaloEG. 2014. Cervical Changes in Estrogen Receptor Alpha, Oxytocin Receptor, LH Receptor, and Cyclooxygenase-2 Depending on The Histologic Compartment, Longitudinal Axis, and Day of The Ovine Estrous Cycle. Theriogenology 81. Issue 6: 813-824.

Toelihere MR. 1993. Livestock Artificial Insemination. Angkasa, Bandung.

Vidal BR, Silva GFD, Santos JS, Dias FEF, Lima AKF, Viana EB,Neves WC, Viana GEN, Gomes MGT and Cavalcante TV. 2013. Estrous Identification Through Colpocytology in Sows in Intensive FreeRange Breeding. Journal of Veterinanry Advances 3(10):281-284.

Vivanco HW. 1986. Recent Developments in Reproductive Technioues of Sheep and Goats. Small Ruminant Production in the Developing Countries. Proceedings of an Expert Consultation. Food and Agriculture Organization of the United Nations. Roma. 33.

Widiyono I, PP Putro, Sarmin, P Astuti, and CMAirin. 2011. Estradiol and Progesterone Profile in Serum, Characteristics of Vulva and Cytology of Vagina in Bligon Goat during Estrous Cycle . Journal of Veterinary 12(4): 263-268.

Zaid NW. 2011. Metachromasia in the exfoliated vaginal cells of awassi ewes. Kufa Journal for Veterinary Medical Sciences 2(1): 114-120 